COLLOQUIA THEOLOGICA OTTONIANA 2/2017, s. 87-102

DOI: $10.18276 /$ cto.2017.2-05

\title{
THE ROLE OF GENESIS ACCOUNT OF CREATION IN THE DEVELOPMENT OF MONOGAMY IN THE OLD TESTAMENT AND ITS RECEPTION IN THE EARLY CHURCH
}

\author{
Marcin Krycki* \\ Wydział Humanistyczny Uniwersytetu Szczecińskiego
}

\section{Introduction}

John Paul II in his Wednesday Catechesis on the theology of the body, addressing the issue of the unity and indissolubility of marriage, indirectly indicates the problem of the difference between the sources Jesus and the Pharisees appealed to in the controversy on the issue of divorce. As presented by the latter, the foundation of the Israel's understanding of the nature of marriage was based on the Mosaic Law. Jesus, in contrast to Pharisees appealed to the beginning, undoubtedly, as the Pope continuous, he appealed to the Book of Genesis ${ }^{1}$.

Although the question of the Pharisees strictly deals with the issue of divorce, however, it also implies the minimalistic and legalistic understanding of marriage: "Christ does not accept the discussion on the level on which his interlocutors tried to introduce it; in a sense, he does not approve the dimension they tried to give

* Fr. Marcin Krycki - priest of the Archdiocese of Szczecin-Kamień. Postgraduate student at the Institute of Philosophy at the Faculty of Humanities of the University of Szczecin. Research interests: bioethics, studies on marriage and family. E-mail: kryckimarcin@gmail.com.

${ }^{1}$ John Paul II, Man and Woman He Created Them: A Theology of the Body, Boston 2006, p. 131-134. 
the problem. He avoids entangling himself in juridical or casuistic controversies; instead, he appeals twice to the "beginning"'

As John Paul II continues, those texts from the Book of Genesis are not of legalistic nature, but rather metaphysical, therefore, Jesus indicates that the entire problem pertains to the understanding of what human being, in general, and marriage, in particular, is.

Therefore, as indicated by Pope John Paul II, there was a problem of the foundation of the understanding of marriage. Although, it may seem, following the way of thinking of the Pharisees, it was the Law of Moses that was the foundation of marriage customs in Israel, I will argue in my paper, that the account of creation played a significant role in shaping the culture of Israel regarding monogamy. This understanding of marriage as presented by Christ by recalling the "beginning" was carried on to the Church. Although the first Christians were guided in many aspects of their lives by the Mosaic Law, nevertheless, their comprehension of marriage was based on the account of creation, as indicated by Christ.

\section{The Old Testament Process of Displacing Polygamy by Monogamy}

\subsection{Polygamy in Judaism}

Biblical scholars agree that polygamy was undoubtedly a part of life in the Old Testament Judaism ${ }^{3}$. Louis Epstein shows that since there are no records of the origins of Hebrew life (their go back to the dawn of human history), "there is room for speculation whether this [polygamous] tradition is native with the Hebrews or was acquired during their history as a result of foreign influences"4. He argues that the biblical records lead to two possibilities: (1) the Hebrew family was essentially monogamous and because of foreign influence polygamy was tolerated as deviation from the standard, or (2) polygamy was the norm of Hebrew family life

\footnotetext{
${ }^{2}$ Ibidem, p. 132.
}

${ }^{3}$ Among others: D.I. Brewer, Jesus' Old Testament Basis for Monogamy, in: The Old Testament in the New Testament: Essays in Honour of J.L. North, ed. S. Moyise, Sheffield 2000, p. 74-75; J. Pedersen, Israel, Its Life and Culture, Vol. 1, Atlanta, Ga. 1991, p. 70-71; E. Neufeld, Ancient Hebrew Marriage Laws, London 1944, p. 118-121; L.M. Epstein, Marriage Laws in the Bible and the Talmud, Cambridge, Mass. 1942, p. 3-12.

${ }^{4}$ L.M. Epstein, op. cit., p. 3. 
and certain internal developments operated toward the ideal of monogamy ${ }^{5}$. After a short analysis of the Old Testament texts Epstein concludes, that: "it seems to us that the evidences advanced in support of the theory of polygamy are more compelling than those offered to support monogamy. (...) Though we find the view of those who maintain that polygamy is rooted in native Hebrew life more plausible and more acceptable to us, we do not go to the whole distance with them in their arguments. We do not claim a native Hebrew tradition of polygamy. (...) The extent to which we do go with this view is that polygamy was an established institution in Hebrew society from time immemorial"6.

In his analysis of the issue, Epstein argues that the monogamous tendencies grew with the progress of Hebrew history influenced by the law-giver and preacher. It was impossible to get rid of polygamy in a short period of time by outright prohibition, thus he had to eliminate it gradually. The preacher taught monogamy through various biblical narrations e.g. by the story of creation, by the story of Solomon, by the words of the prophets, and by apologies for the polygamy of some prominent biblical persons?

Francis Martin presents opposite point of view. He agrees that polygamy indeed existed in Israel, it was presumed, however never legislated in any positive sense. It was monogamy that was increasingly considered to be the norm and the ideal, not only in the sapiential and prophetic literature, but eventually in legal texts as well. Martin makes a conclusion that it may be said of polygamy in Israel that it was discouraged and perhaps actually legislated against ${ }^{8}$. The first part of his argumentation is consistent with those of most of the scholars, although the last statement is hard to defend, since Martin does not refer to any biblical passages, neither to any reliable survey.

Following the argumentation of Epstein, it must be said that polygamy (and polygyny) appears to have been practiced in throughout most of the pre-exilic period in Israel. There are many biblical texts that show frequency of polygamous marriages among the leading personalities of the Bible. Those of whom polygamy

${ }^{5}$ Ibidem.

${ }^{6}$ Ibidem, p. 6-7.

${ }^{7}$ Ibidem, p. 5-6.

${ }^{8}$ F. Martin, Marriage in the Old Testament and Intertestamental Periods, in: Christian Marriage: A Historical Study, ed. G.W. Olsen, New York 2001, p. 17. 
is recorded are: Lamech, Abraham, Nahor, Essau, Jacob, Simeon, Gideon, Elkanah, Saul, David, Solomon, Reboham, Jehoash, Abiah, Manasseh, and Sherahim 9 .

David Brewer points out that the Mosaic Law allows polygamy ${ }^{10}$, although it never speaks about it with approval. These practices were quite common after times of war when the population was diminished. Polygamy was also related to childlessness, since the maintenance of the family was one of the most ethical demands of old Israel ${ }^{11}$.

Polygamy in Israel had almost the same consequences as in other nations. Families were usually divided into sub-families because the wives usually rivaled each other, what affected also the children. Sometimes antagonism between the wives even took the form of open hatred. It was quite common in Israel that one of the wives was called "beloved" or primary wife, because of her capacity for bearing children or because of other factors (sometimes it was nothing more than caprice of the husband) $)^{12}$.

Royal polygamy was a different case. The marriage between the king and a woman from another country was a political arrangement in order to maintain peace or alliance between these two countries. Large amount of wives could also be a sign of wealth and power of the king ${ }^{13}$. There was also a case when the ruler's wives and concubines passed to his successor ${ }^{14}$. In the Old Testament the criticism of polygamy was also pointed to the many wives of kings (some of whom were foreigners) ${ }^{15}$.

Polygamy was formally prohibited in Judaism in the eleventh century by the Herem of R. Gershom of Mayence (960-1040 CE). Although it had probably ceased to be practiced long before this ${ }^{16}$. Gordon Hugenberger shows that the process of disappearing of polygamous marriages in the history of Israel started in the post-exilic period. He claims that "monogamy was seen as the marital ideal in this period and that actual marital practice was monogamous with few, if any,

${ }_{9}^{9}$ Gen. 4:19; 16:3; 22:24; 28:9; 29:23f.; 46:10; Judg. 8:30; 1 Sam. 1:2; 2 Sam. 3:2f; 5:13;

12:8; 1 Kings 11:3; 1 Chron. 7:14; 2 Chron. 11:21; 13:21; 24:3; cf. L.M. Epstein, op. cit., p. 4.

${ }^{10}$ Cf. Exod. 21:10-11; Deut. 21:15-17; Lev. 18:18.

${ }^{11}$ D.I. Brewer, op. cit., p. 75; J. Pedersen, op. cit., p. 70.

${ }^{12}$ Cf. E. Neufeld, op. cit., p. 120-121.

${ }^{13}$ Cf. F. Martin, Marriage in the Old Testament..., p. 17, 71f; D.I. Brewer, op. cit., p. 76.

${ }^{14}$ Cf. 2 Sam. 16:20-22.

${ }^{15}$ Cf. Deut. 17:17.

${ }^{16}$ D.I. Brewer, op. cit., p. 78. 
exceptions"17. According to many scholars the account of creation from Genesis, many laws of the Pentateuch and statements in the wisdom literature appear to support monogamy as the normal or ideal marriage form ${ }^{18}$.

The abovementioned scholars' research leads to the conclusion that polygamy was present as a part of life in Israel from the time immemorial. Even though in some cases polygamy was allowed and tolerated by Jewish law, it was never considered as a normal (as intended by God) form of family life. It seems to be necessary to look at the process of establishing of monogamy as model form of marriage. In this process the account of creation from Genesis was one of the crucial factors shaping the consciousness of Israelites, especially after the exile.

\subsection{The Significance of the Account of Creation in the Process of Development of Monogamy in the Old Testament}

In post-exilic biblical texts marriage and infractions of marital obligations were no longer shown as merely private matters, but became the subject of covenantal code. What is more important, is that marriage itself was considered as a covenant between man and woman, which reflected the covenant between Yahweh and the people of Israe ${ }^{19}$. In regard to the post-exilic tradition, Martin remarks that: "one aspect of wisdom tradition thinking (...) deserves very special attention. It is the effort of the sages of Israel to understand the mystery of the origins of the universe and specifically of the human race"20.

The first of the two passages regarding creation is Gen. 1:1-2:3, which is considered a part of "Priestly" tradition ${ }^{21}$. This passage is a poetic discourse on the origin

${ }^{17}$ G.P. Hugenberger, Marriage as a Covenant: Biblical Law and Ethics as Developed from Malachi, Grand Rapids, Mich. 1998, p. 121.

${ }^{18}$ The supporters of this point of view, according to Hugenberger, are: Wilhelm Nowack, Ernst Sellin, Reuven Yaron, Bruce Vawter, Stefan Shreiner, Angelo Tosato, Elizabeth Achtemeier, and Beth Glazier-MsDonald.

${ }^{19}$ F. Martin, Marriage in the Old Testament..., p. 20.

${ }^{20}$ Ibidem, p. 21.

${ }^{21}$ Claus Westerman addressing the issue of the origin of Gensesis 1-11 argues that: "For the written stage, we can agree with generations of scholars that Genesis 1-11 is a composite of two written works, J (the "Yahwist," tenth-ninth century), and P (the "Priestly source," sixth-fifth century) (...). In the case of the oral stage, however, research is still very much in flux. Herman Gunkel and others first recognized that $\mathrm{J}$ and $\mathrm{P}$ are not authors in our sense of the word, but are primarily tradents who fashioned the traditional materials into a single work, a cohesive Primal History. They worked not only as tradents, but as authors and theologians as well. Three tradents contributed to the final written form-J, P, and R (Redactor). But innumerable voices shared in the oral stage, for stories 
of the world and of man as the crown of creation. This text can be called a narrative only in an extended sense, because it is a literary presentation of a completed action, and that action is rather described than narrated ${ }^{22}$. The highest point of this passage is the creation of man ( $\bar{a} \underline{d} \bar{a} m)^{23}$. "Then God said, 'Let us make man in our image, after our likeness; and let them have dominion over the fish of the sea, and over the birds of the air, and over the cattle, and over all the earth, and over every creeping thing that creeps upon the earth.' So God created man in his own image, in the image of God he created him; male and female he created them. And God blessed them, and God said to them, 'Be fruitful and multiply, and fill the earth and subdue it; and have dominion over the fish of the sea and over the birds of the air and over every living thing that moves upon the earth"' (Gen. 1:26-28).

This passage, through the description of $\bar{a} \underline{d} \bar{a} m$ as male and female, places sexual differentiation within a world created by God, and affirms human sexuality as good. Following Martin's interpretation, one can notice that sex is not shown as a means of cultivating cosmic powers (like in fertility cults in Mesopotamia and Canaan), but as something properly human, which expresses the way in which humans image $\mathrm{God}^{24}$. This image is evident in a parallel: "as God creates in his image as his likeness, Adam begets in his likeness as his image, and Eve acquires a man-child with the help of Yhwh (...). Male and female are described as making up the humanity that images God before they are blessed and made fruitful”25.

Addressing the issue of the Genesis' indications of monogamy, Brewer refers to the exegesis of Evald Lövestam ${ }^{26}$. This exegesis is based on the rabbinic method called gezerah shavah which consists in linking two texts by a shared phrase and applying the definitions or descriptions from one text to the other. Lövestam points out that

passed form mouth to mouth. (...) These narratives had already existed for decades, even centuries, before being written down-not as a tradition known and handed on by only a few people, but rather as an element integral to the life, thought, culture, and religious faith of the people of Israel and their forebears. It was an indispensable element of their history; they lived with these stories". In: C. Westermann, Genesis: A Practical Commentary, Grand Rapids, Mich. 1987, p. 2.

${ }^{22}$ Cf. F. Martin, Male and Female He Created Them: A summary of the Teaching of Genesis Chapter One, "Communio" 20 (1993), Summer, p. 243.

${ }^{23}$ This word means human being in general, without indicating gender or pointing to any concrete name.

${ }^{24}$ Cf. also V.P. Hamilton, The book of Genesis: Chapters 1-17, Grand Rapids, Mich. 1990, p. 139.

${ }^{25}$ F. Martin, Male and Female..., p. 254-255.

${ }^{26}$ E. Lövestam, Divorce and Remarriage in the New Testament, in: B.S. Jackson, The Jewish Law Annual, Vol. 4, Leiden 1981, p. 50. 
Gen. 1:27 and 7:9 are linked by the words "male and female." On one hand, Gen. 7:9 indicates that the phrase "male and female" means a pair, since they went into the ark "two by two," on the other, Gen. 1:27 shows that God himself was responsible for putting the male and female together. Employing gezerah shavah method, Lövestam concludes that these texts can be used to show that God put men and women together in pairs. Thus, it can be inferred that God instituted marriage as one husband and one wife. Although marriage is not mentioned in either text, but in Gen. 1:28 God blessed them and told them to multiply, so it could be deduced that marriage was implied. Moreover, Brewers continues, the first text of creation refers to the beginning, thus "if God did something one way, we should follow his example"27.

The second Biblical text concerning creation of the world is Gen. 2:4-25, which belongs to the "Yahwist" tradition. Richard Davidson shows that many modern scholars ${ }^{28}$ likewise recognize that the second account of creation clearly reveals that the divine design for marital form is monogamy ${ }^{29}$. In this analysis the most important is the passage regarding creation of man and woman: "then the LORD God formed man [ādām] of dust from the ground, and breathed into his nostrils the breath of life; and man [ādām] became a living being. [...] So the LORD God caused a deep sleep to fall upon the man [ādām], and while he slept took one of his ribs and closed up its place with flesh; and the rib which the LORD God had taken from the man [ādām] he made into a woman [iššă $\left.\bar{a}^{\mathrm{h}}\right]$ and brought her to the man. Then the man [ādām] said, 'This at last is bone of my bones and flesh of my flesh; she shall be called Woman [iššă $\left.{ }^{\mathrm{h}}\right]$, because she was taken out of Man [î̌s].' Therefore a man [î̌s leaves his father and his mother and cleaves to his wife [iššă $\left.{ }^{\mathrm{h}}\right]$, and they become one flesh". (Gen. 2:7; 21-24)

In the latter part of the text (Gen. 2:23) there is an instance of etymology, a derivation based on assonance: "she shall be called woman [iššă $\left.{ }^{\mathrm{h}}\right]$, because she was taken out of man [î̌s]." Victor Hammilton points out, that the text does not say "she shall be called female [nəqēb $\bar{a}^{\mathrm{h}}$ ], because she was taken out of male

${ }^{27}$ D.I. Brewer, op. cit., p. 86-87.

${ }^{28}$ Among others: W. Vogels, Man and Woman-Their Dignity, Mutuality, and Fidelity in Marriage: A Biblical Perspective (Gen 1-3), "Bible Bhashyam" 23 (1997), p. 223-224; W. Loader, The Septuagint, Sexuality, and the New Testament: Case Studies on the Impact of the LXX in Philo and the New Testament, Grand Rapids 2004, p. 42; W. Neuer, Man and Woman in Christian Perspective, Wheaton, Ill 1991, p. 168.

${ }^{29}$ R.M. Davidson, Flame of Yahweh: Sexuality in the Old Testament, Peabody, Mass. 2007, p. $21-22$. 
[zākāar]," therefore the narrator by using these two words that sound alike wished to emphasize the identity and equality of the primal couple ${ }^{30}$.

The creation of woman from one of man's rib, according to Westerman, is not to be understood as factual description. The narrator tries to ground the intimate relationship between man and woman in the process of creation ${ }^{31}$. The creation of woman supplies what was missing for man's perfect happiness. This passage contains a hint of poetry, which is missed if one reads it as an account of a clinical operation or as an attempt to explain some feature of man's anatomy. Rather, as Umberto Cassuto shows, it brilliantly depicts the relation of man and wife: "just as the rib is found at the side of the man and is attached to him, even so the good wife, the rib of her husband, stands at his side to be his helper-counterpart, and her soul is bound up with his" ${ }^{\prime 32}$. The phrase "bone of my bones and flesh of my flesh" indicates the unity of nature of man and wife ${ }^{33}$. Such close and intimate relationship of the first couple shown in the second chapter of Genesis can be considered as an argument for monogamy. Since in the polygamous marriage the husband is not capable to set undivided, sole love on all of his wives, polygamy is set far away of the ideal depicted in the book of Genesis.

The first couple's relationship can be called the archetypal marriage form presented by God for humans as a paradigm for a monogamous marriage. There are several arguments in the text that support this thesis. The first argument is based on the consecutive usage of singular nouns and pronouns: God makes "him a helper fit for him" (Gen. 2:18), God "took one of his ribs" and the rib God made "into a woman and brought her to the man" (Gen. 2:21-22), beholding what God had made "the man said (...) she shall be called Woman, because she was taken out of Man" (Gen. 2:23). Obviously, the text denotes a union between one man and one woman. In Gen. 2:24 the phrase "a man (...) cleaves to his wife" with both nouns in singular, clearly implies that the sexual relationship is intended to be monogamous, and should be shared between two marriage partners. The Septuagint translation makes this point more explicit by adding a numeral adjective "two" in the mentioned verse ${ }^{34}$.

${ }^{30}$ V.P. Hamilton, op. cit., p. 180; to this interpretation refers also John Paul II in: op. cit., p. 139.

${ }^{31}$ C. Westermann, op. cit., p. 21.

${ }^{32}$ U. Cassuto, A Commentary on the Book of Genesis 1-11, Jerusalem 1961, p. 134.

${ }^{33}$ E.H. Maly, Genesis, in: The Jerome Biblical Commentary, eds. R.E. Brown, J.A. Fitzmyer, R.E. Murphy, Englewood Cliffs, N.J. 1968, p. 12.

${ }^{34}$ Bible Works Greek LXX/BNT Gen. 2:24: "kai esontai hoi duo eis sarka mian" ("and they two shall become one flesh"). 
Wide range of the Old Testament texts witness to the process of eradicating polygamy. The account of creation as an opening part of Pentateuch (which is the most important part of Jewish scriptures), plays a significant role in this process, since it appeals to the primal God's design and thus serves a model for human relationships. It is possible to make a hypothesis that the process of redaction of the Book of Genesis (which was accomplished about the fifth century BC) integrated in the book the elements of the tradition which had already existed for centuries in the consciousness of the Israelites. One part of this tradition was the idea of monogamy as consistent with Yahweh's will concerning marriage. Thus, it is most likely that the first two chapters of Genesis radically influenced the process of strengthening monogamy especially in post-exilic period.

\section{Jesus' Old Testament Basis for Monogamy}

The Genesis account of creation had a strong influence not only in the Old Testament times, but also in Jesus' times. In two Gospels: according to Matthew and Mark it is recorded that Jesus refers to the beginning in the discussion with the Pharisees concerning indissolubility of marriage.

\subsection{The Context of Jesus' Discussion with the Pharisees}

Since the second-temple period ${ }^{35}$ in Israel there was going a well-known debate between the schools of Hillel the Elder ${ }^{36}$ and Shammai the Elder ${ }^{37}$ concerning the problem of grounds for divorce. The crux of the matter was the fact that the followers of these schools proposed different interpretations of Deut. 24:138. The Mishnaic tractate Gittin in classical rabbinic style summarized the essence of the arguments: "The School of Shammai says: A man may not divorce his wife unless he has found unchastity in her, for it is written, Because hath found in her indecency in anything. And the School of Hillel says: (He may divorce her) even if

${ }^{35}$ The second-temple period in Jewish history lasted between $530 \mathrm{BC}$ and $70 \mathrm{CE}$, when the Second Temple of Jerusalem existed.

${ }^{36}$ The greatest Jewish scholars of the second-temple period.

${ }^{37}$ One of the principal leaders of the Sanhedrin in the second-temple period.

${ }^{38}$ Cf. R.F. Collins, Divorce in the New Testament, Collegeville, Minn. 1992, p. 75. 
she spoiled a dish for him, for it is written, Because he hath found in her indecency in anything" 39 .

Only two Gospels, viz. according to Matthew and Mark, recorded the discussion between Jesus and the Pharisees: "And Pharisees came up to him and tested him by asking, 'Is it lawful to divorce one's wife for any cause?' (...) And I say to you: whoever divorces his wife, except for unchastity, and marries another, commits adultery" (Matthew 19:3,9). "And Pharisees came up and in order to test him asked, 'Is it lawful for a man to divorce his wife?' (...) And he said to them, 'Whoever divorces his wife and marries another, commits adultery against her; and if she divorces her husband and marries another, she commits adultery" (Mark 10:2, 11-12).

In the Gospel according to Matthew the two highlighted expressions, "for any case," and "except for unchastity," play an important role, since they unveil the background of Jesus' answer, which is the aforementioned rabbinic debate concerning divorce. The similar scene is recorded in the Gospel according to Mark; however in that gospel relation to the debate is not so obvious. The Pharisees, as it is shown in both gospels, asked Jesus about the interpretation of Deut. 24:1-4, which is to only one Old Testament text which deals with the divorce certificate. Although, before Jesus answered this question, he emphasized also issues concerning monogamy and indissolubility of marriage, which he found very important.

\subsection{The Line of Jesus' Argumentation}

But from the beginning of creation, He answered, "Have you not read that "God made them male and female." he who made them from the beginning [Gen. 1:27] "For this reason a man made them male and female [Gen. shall leave his father and mother and 1:27], and said, 'For this reason a man be joined to his wife, and the two [Gr. shall leave his father and mother and $d u o$ ] shall become one flesh." [Gen be joined to his wife, and the two [Gr. 2:24] So they are no longer two but one duo] shall become one flesh'? [Gen. flesh. What therefore God has joined 2:24] So they are no longer two but one together, let not man put asunder." (Mark 10:6-9)

flesh. What therefore God has joined together, let not man put asunder." (Matt. 19:4-6)

${ }^{39}$ Mishna Gittin 9:10; as quoted in R.F. Collins, op. cit., p. 75. 
Both gospels show that before Jesus answered the question of Pharisees and made an authoritative interpretation of Deut. 24:1, he reminded that from the beginning marriage was intended to be monogamous and lifelong. What is more important, Jesus refers to both Old Testament accounts of creation and combines them in order to make a conclusion that marriage partners are joined together by God, and therefore any human instance cannot change it.

Analyzing these passages, Brewer insists that in the first stage of Jesus' argumentation, the reference to Gen. 1:27 (and indirectly to Gen. 7:9) in Mark 10:6 (and even clearly in Matt. 19:4) is very similar to the opening phrase characteristic for the Damascus Document (CD 4.21: "while the foundation of creation is"). This introductory phrase indicates that the importance of the exegesis lies in the fact that this is the example that the Creator set for everyone else. Although Brewer does not claim that Jesus consciously or unconsciously referred to the Damascus Document, but "[i]t is more likely that this was a standard proof for monogamy which was well known. For this reason both Jesus and the Qumran exegete start off with this proof" 40 .

The second stage of Jesus' argumentation against polygamy and divorce is reference to Gen. 2:24. Additional numeral adjective "two" (Gr. duo) is present in both Synoptic Gospels, Matthew and Mark. In fact, this additional word is present in almost all the ancient versions of the text except Hebrew ${ }^{41}$. It must be assumed that this variant of the text is used not incidentally, but reflects the intention of Jesus Christ. This conclusion is supported by the next verse, which highlights the presence of this adjective: "so they are no longer two [Gr. duo] but one flesh".

Using abovementioned method gezerah shavah, one can notice that Jesus combined two Old Testament arguments for monogamy, which comes from two accounts of Creation in Genesis 1-2, in order to construct an argument for indissolubility of marriage. The common, linking words are: "male and female" in Gen. 1:27 and "man and his wife" in Gen. 2:25. In the second account of creation the act of joining is not ascribed to anyone, thus it can be assumed that man and his wife join themselves to each other. However in the first account of creation man and woman are created and brought together by the creative act of God. Through

${ }^{40}$ D.I. Brewer, op. cit., p. 97.

${ }^{41}$ Brewer gives a clue to solve this inconsistence: "It is possible that there was a Hebrew text which contained this variant [adjective "two"], but the widespread use of this variant in ancient versions in contrast to the most influential Hebrew text, suggests that there was either a theological reason for including it or a contrary theological reason for the rabbis to exclude it. The actual situation was probably a mixture of these two." (D.I. Brewer, op. cit., p. 98). 
gezerah shavah Jesus communicates the truth that a couple is joined together by God. Hence, the primary intention of the Creator (for lifelong marriage of one man and one woman) is more authoritative than Mosaic right to write a certificate of divorce, which was given "for hardness of [Israelites'] heart" (Matt. 19:8; Mark 10:5) $)^{42}$.

\section{The account of Creation in Early Church Fathers}

It would exceed the scope of this paper to describe profoundly the entire teaching of the Early Church Fathers regarding the nature of marriage and its development. For the present concern, the witness of the most prominent Fathers of the Church is sufficient to indicate that the account of creation became the foundation of the monogamous understanding of marriage. Although, it needs to be noticed that there was also a development of the precise meaning of the passage, what was a basis of the arguments on the allowance of divorce in case of fornication or on the non-possibility of another marriage after the death of one's own spouse.

The Fathers of the Church, which witness to the formation of the doctrine of the Early Church, described the nature of marriage following the teaching of Christ. They not only understood Christ's appeal to Genesis as dealing strictly with the question of divorce (which could as well imply the polygamous unions with the prohibition of divorce of each wife) but they directly taught that the account of creation is normative for the monogamous marriage.

In Exhortation to Chastity Tertullian wrote: "I will call your attention to the law of monogamy. The very origin of the human race sanctions it" ${ }^{\text {"3 }}$. The idea behind this understanding was that the act of creation of a man and a woman establishes the norm on marriage. Tertullian concludes that if God plan had included polygamous unions then God would have created one man and many women ${ }^{44}$. It is similarly stated in Incomplete Work on Matthew: “'Male and female.' Not male and many females, so that a man is allowed to possess many wives, nor males and

${ }^{42}$ Cf. ibidem, p. 98-100; F. Martin, Marriage in the New Testament Period, in: Christian Marriage: A Historical Study, ed. G.W. Olsen, New York 2001, p. 52-53.

${ }^{43}$ Tertullian, Exhortation to chastity, 5 as quoted in: Ancient Christian Commentary on Scripture. New Testament. II. Mark, eds. T.C. Oden, C.A. Hall, Downers Grove, Ill 1998, p. 135.

${ }^{44}$ Ibidem, p. 134-135. 
a female, so that one woman is allowed to have many husbands" ${ }^{\prime 4}$. Chrysostom in one of his homilies on the Gospel of Matthew reminded: "one man must dwell

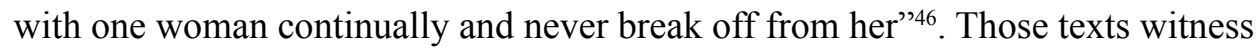
that the interpretation of Genesis among the fathers was a basis of the monogamous marriage.

The prohibition of another marriage in the early Church had actually two facets, which were debated in the Early Church: (1) the prohibition forbids any other marital union even after the death of one's own spouse ${ }^{47}$, or (2) the prohibition forbids polygamy. The Church decided in favor of the second, so St. Augustine taught clearly that: "the husband is also bound, as long as his wife is alive", in any other case, the polygamy was considered as sinful ${ }^{48}$.

Although the account of creation was normative for the Fathers, they discovered, in the light of Christ, another dimension of its prescriptiveness. It was not only the "arbitrary" decision of the Creator to legislate for monogamous marriage, but the Fathers considered its exemplarity as a prophecy regarding the union between Christ, the bridegroom, and the Church, his bride. Marriage as a sign of mutual love of Christ and the Church is shown in the works of Origen, who wrote: "The apostle understands 'the two shall become one flesh,' as referring to Christ and the church"49. In this perspective Jacob of Sarug added: "The prophet Moses spoke of man and woman in this way in order to foretell Christ and his church" 50 . He defends Moses and the permission of the "bill of divorce" recognizing it as a sign of prophecy that was to be fulfilled with the coming of Christ when the true nature of marriage as sacramental would be established ${ }^{51}$.

${ }^{45}$ Incomplete Work on Matthew. Homily 32, as quoted in: Ancient Christian Commentary on Scripture. New Testament. Ib. Matthew 14-28, ed. M. Simonetti, Downers Grove, Ill 2002, p. 91.

${ }^{46}$ Chrysostom, The Gospel of Matthew, Homily 62.1, as quoted in: Ancient Christian Commentary..., ed. M. Simonetti, p. 91.

${ }^{47}$ Athenagoras, A Plea Regarding Christians, 33: "We hold that a man should remain as he is born or else marry only once. For a second marriage is a veiled adultery." as quoted in: Ancient Christian Commentary..., eds. T.C. Oden, A. Hall, p. 136.

${ }^{48}$ Augustine, Adulterous Marriages, 2.9.8, as quoted in: Ancient Christian Commentary..., eds. T.C. Oden, A. Hall, p. 136.

${ }^{49}$ Origen, Commentary on Matthew, 14.17, as quoted in: Ancient Christian Commentary..., ed. M. Simonetti, p. 92.

${ }^{50}$ Jacob of Sarug, Homilies, as quoted in: Ancient Christian Commentary..., eds. T.C. Oden, A. Hall, p. 135-136.

${ }^{51}$ Cf. ibidem. 


\section{Conclusion}

There is one final question that remains open on the question of the account of Genesis and Christ appealing to it. The Gospel of Matthew contrasts the teaching of the Book of Genesis and the original account of creation with the Law of Moses. Under the Law of Moses the polygamy was permissible while the monogamy remained an ideal. Christ was able to place this ideal as normative and possible to fulfill, only because he offered the humanity what Moses could not. Namely, Christ by his death and resurrection, made possible to restore the original meaning of creation, including marriage. In Christ monogamous sacramental marriage fulfilled its prophetic function as the union between Christ and the Church. Following the lead of the Fathers, it can be noticed that only in Christ the original significance of creation is truly fulfilled, only in him man can go "to the beginning."

\section{Bibliography}

Ancient Christian Commentary on Scripture. New Testament. Ib. Matthew 14-28, ed. M. Simonetti, Downers Grove, Ill 2002.

Ancient Christian Commentary on Scripture. New Testament. II. Mark, eds. T.C. Oden, C.A. Hall, Downers Grove, Ill 1998.

Brewer D.I., Jesus' Old Testament Basis for Monogamy, in: The Old Testament in the New Testament: Essays in Honour of J.L. North, ed. S. Moyise, Sheffield 2000, p. 75-105.

Cassuto U., A Commentary on the Book of Genesis 1-11, Jerusalem 1961.

Collins R.F., Divorce in the New Testament, Collegeville, Minn. 1992.

Davidson R.M., Flame of Yahweh: Sexuality in the Old Testament, Peabody, Mass. 2007.

Epstein L.M. Marriage Laws in the Bible and the Talmud, Cambridge, Mass. 1942.

Hamilton V.P., The book of Genesis: Chapters 1-17, Grand Rapids, Mich. 1990.

Hugenberger G.P., Marriage as a Covenant: Biblical Law and Ethics as Developed from Malachi, Grand Rapids, Mich. 1998.

John Paul II, Man and Woman He Created Them: A Theology of the Body, Boston 2006.

Lövestam E., Divorce and Remarriage in the New Testament, in: B.S. Jackson, The Jewish Law Annual, Vol. 4. Leiden 1981, p. 47-65.

Maly E.H. Genesis, in: The Jerome Biblical Commentary, eds. R.E. Brown, J.A. Fitzmyer, R.E. Murphy, Englewood Cliffs, N.J. 1968, p. 7-46.

Martin F., Male and Female He Created Them: A summary of the Teaching of Genesis Chapter One, "Communio" 20 (1993), Summer, p. 240-265. 
Martin F., Marriage in the New Testament Period, in: Christian Marriage: A Historical Study, ed. G.W. Olsen, New York 2001, p. 1-49.

Martin F., Marriage in the Old Testament and Intertestamental Periods, in: Christian Marriage: A Historical Study, ed. G.W. Olsen, New York 2001, p. 50-100.

Neufeld E., Ancient Hebrew Marriage Laws, London 1944.

Pedersen J., Israel, Its Life and Culture, Vol. 1, Atlanta, Ga. 1991.

Westermann C., Genesis: A Practical Commentary, Grand Rapids, Mich. 1987.

\section{ROLA OPISU STWORZENIA Z KSIĘGI RODZAJU W ROZWOJU MONOGAMII W STARYM TESTAMENCIE I JEGO RECEPCJA W PIERWOTNYM KOŚCIELE}

\section{Streszczenie}

Analiza tez biblistów dotyczących poligamii w Starym Testamencie prowadzi do konkluzji, że była ona praktykowana w starożytnym Izraelu. Znawcy tematu podają dwie ewentualności: albo poligamia była częścią kultury semickiej od zarania jej dziejów, albo była późniejszym skutkiem wpływów kultury ludów ościennych. Niemniej, jak podaje autor artykułu, istnieją niezbite dowody, że poligamia nigdy nie była tolerowana jako normalna, zamierzona przez Boga forma życia rodzinnego. Główną tezą artykułu jest stwierdzenie, że opis stworzenia z Księgi Rodzaju istotnie wpłynął na rozwój monogamii w kulturze starożytnego Izraela. Opisana relacja pierwszej pary ludzi miała na celu prezentować archetypiczną formę małżeństwa zaproponowaną przez Boga ludziom jako paradygmat monogamicznego małżeństwa. Artykuł ukazuje, że prawdopodobna jest hipoteza biblistów, że proces redakcji Księgi Rodzaju (ukończonej około V wieku przed Chrystusem) zintegrował w tekście elementy tradycji monogamicznej, które były obecne w świadomości Izraelitów od wieków, jednocześnie stał się wzorcem życia małżeńskiego dla kolejnych pokoleń i pomógł wykorzenić ślady myślenia poligamicznego. Artykuł porusza również sporną kwestię rozwodów dyskutowaną przez szkoły rabinackie Hillela Starszego i Shammaia Starszego, do której odniósł się Jezus w Ewangelii, odwołując się do opisu stworzenia z Księgi Rodzaju. Przedstawione w tekście wybrane wypowiedzi Ojców Kościoła dotyczące monogamii również wskazują, jak istotną rolę odgrywa opis stworzenia z Księgi Rodzaju w formowaniu chrześcijańskiej świadomości odnośnie do małżeństwa.

Słowa kluczowe: monogamia, poligamia, małżeństwo w Starym Testamencie, Ojcowie Kościoła, Księga Rodzaju 


\title{
THE ROLE OF GENESIS ACCOUNT OF CREATION IN THE DEVELOPMENT OF MONOGAMY IN THE OLD TESTAMENT AND ITS RECEPTION IN THE EARLY CHURCH
}

\begin{abstract}
Summary
The analysis of biblical scholars' teaching on polygamy in The Old Testament leads to the conclusion that it was practiced in the ancient Israel. Experts in this field give two possibilities: either polygamy was a part of the Semitic culture from the dawn of history, or it was later effect of the influences of the culture of neighboring peoples. However, as the author of the article claims, there are irrefutable proofs that polygamy was never tolerated as normal, intended by God form of family life. The main thesis of the article is the conviction that the account of creation from the Book of Genesis substantially influenced the evolution of monogamy in the culture of the ancient Israel. Described relation of the couple of the first people had to be an archetypical form of marriage presented by God and proposed for people as a paradigm of the monogamous marriage. The article shows that it is probable the hypothesis of the biblical scholars expressing the conviction that the process of redaction of the Book of Genesis (finished around 5th century BC) integrated in its content elements of the monogamous tradition that was present in the consciousness of the Israelites from centuries; what is more, it became the paradigm for the marital life for later generations and it helped to get rid of the traces of the polygamous mindset. The article also describes the controversial debate concerning divorce between rabbinical schools of Hillel the Elder and Shammai the Elder; as the Gospel presents Jesus Christ refers to this quoting the passage on creation from the Book of Genesis. Presented in the article selected excerpts from the Church Fathers on monogamy also pointed to the importance of the Genesis account of creation in forming the Christian vison of marriage.
\end{abstract}

Keywords: monogamy, polygamy, marriage in the Old Testament, the Church Fathers, the Book of Genesis 